City University of New York (CUNY)

CUNY Academic Works

\title{
Thoughts on Reading "The Personal": Toward a Discursive Ethics of Professional Critical Literacy
}

Jane Hindman

CUNY Guttman Community College

\section{How does access to this work benefit you? Let us know!}

More information about this work at: https://academicworks.cuny.edu/nc_pubs/69

Discover additional works at: https://academicworks.cuny.edu

This work is made publicly available by the City University of New York (CUNY).

Contact: AcademicWorks@cuny.edu 


\title{
Thoughts on Reading "the Personal": Toward a Discursive Ethics of Professional Critical Literacy
}

\author{
Jane E. Hindman
}

It makes little sense to see the expressivist move to the personal as emerging from an inordinate confidence in the capacity of individuals to apprebend untainted trutb; the move is prompted [. . .] by conditions of language and its users.

—Thomas G. O’Donnell, "Politics and Ordinary Language" 432

I

am grateful for the opportunity to put together this special issue. I've discovered that, much like my work in the classroom, editing teaches me as much as if not more than it does the others who sign up for my purported expertise. From selecting the manuscripts, to deciding which reviews to privilege, to recommending revisions, and finally to constructing what I want to say here, this process has enriched and refined my understanding of personal writing and its contributions to scholarly work.

For instance, after reading through all the thirty submissions-even some of the ones that you'll read here-I noted discrepancies between what I and others seem to expect from effective personal writing for scholarly publication. Some writers apparently believe that being asked to write the personal-whether it be a narrative, experiential, affective, and/or embodied piece-frees them from the constraints of writing for readers. As a result, some ignore what I consider necessities, for instance, if not a "thesis," at least a predominant (if not explicitly stated) point as well as a cogent and coherent arrangement of text, even if that text consists of fragmented reflections on a unifying concept. Some scholars - and not just those who submitted manuscripts for this issue - seem to think that personal writing frees them

Jane E. Hindman is associate professor in the Department of Rhetoric and Writing Studies at San Diego State University. Her most recent scholarly efforts are focused on examining our professional "procedures of discourse" in constructing and sustaining disciplinary authority. Articles in which she theorizes and enacts an embodied professional rhetoric have appeared in College English, $7 A C$, Pre/Text, and Pre/Text ElectraLite. 
from the demands of professional academic writing, demands such as making new knowledge of relevance to English studies communities and/or applying existing knowledge(s) and/or theorizing rather than simply relating personal knowledge, regardless of how clever the description.

What I think of as personal writing for an academic audience is simply not that "free." College English readers in particular, steeped in great literature and/or effective rhetoric and expert at evaluating others' essays, may become more impatient with wordy, unfocused, mundane, or irrelevant personal accounts than with academic ones. In addition, regardless of their genre, personal writers must at least consider the focused concerns of College English referees' traditional concerns (articulated on the standard referee questionnaire), such as whether or not the subject will be of general interest to readers of College English, whether previous and current scholarship on the topic is acknowledged, how likely other authors might be to cite the submission, and how readily nonspecialists will understand the article. In other words, like all professional writing, and as my opening reference to O'Donnell's "Politics and Ordinary Language" explains, personal writing must be shaped by "the conditions of language and its users"; it cannot be properly "placed" in the academic unless it's social, that is, constructed for readers in the context in which it is to be received. Referees' rejections of much of my own personal writing have sufficiently persuaded me of that fact.

Another point about what I learned as I read submissions for this issue: I prefer personal writing that's "personal," that stages the author grappling with his or her own self-construction(s). Many others-Min-Zhan Lu comes most readily to mindattend to our "need to imagine ways of using experience critically" ("Reading" 239) as we instruct students how to write their difference and learn ourselves how to read through our own difference and evaluate their work justly, effectively. I, however, am concerned with how to attend to that need in our own scholarly writing as well as in our positions as readers of our colleagues'.

As a result, this issue focuses primarily on embodied personal writing, a scholarly concern of mine for quite some time now. In efforts to identify and argue for a powerful alternative to masculinist discourse, my specific call has been to incorporate an "embodied rhetoric" into our professional discursive practices. Generally speaking, embodied rhetoric "requires gestures to the material practices of the professional group and to the quotidian circumstances of the individual writer," such as the writer's affect, motive(s), history, and/or stakes in the argument or position adopted ("Writing" 103). These unfamiliar, "personal" gestures replace or supplement conventional gestures to an always-already-constituted disciplinary authority, familiar moves such as citing a rigidly surveilled and highly specialized body of disciplinary knowledge; resolving contradictions within or between disciplinary positions; determining the nature and/or tradition of a discipline and whom it should include; or applying or testing a disciplinary theory. 
My call for a more embodied scholarly rhetoric is by no means unique: many other, more notable scholars have made similar arguments in many disciplines. Within composition studies, Patricia Bizzell, for instance, endorses an affective scholarly methodology. Using Jacqueline Jones Royster's Traces of a Stream as an example, Bizzell claims that such an alternative is appropriate not just to feminist research methods and discourses but to all scholarly work in rhetoric and composition. Andrea Lunsford's "Rhetoric, Feminism, and the Politics of Textual Ownership" similarly implores feminists to "create, enact, and promote alternative forms of agency" (535). Likewise, feminist scholar and editor Lynn Worsham, in her explorations of the role of l'écriture féminine in composition studies and in her call for compositionists to construct a "rhetoric of theory," considers the need for more affective, material professional discourse(s) and method(s). Worsham explains that not just social space and knowledge fields but even "what we take to be the most private and personal of phenomena - emotion and the body —are effects of social organization and are made available for public administration through the techniques of discipline"; thus, she continues, in order "to understand the discipline that has evolved to study and teach writing, we must understand the way it works at both the semantic and affective levels to produce and organize knowledge and experience" ("On the Rhetoric of Theory" 397).

It would seem to go without saying that these calls for and responses to an evergrowing expansion in the conventions of the academic essay-in professionals' critical literacy-require similar expansion in the conventions for scholarly consumption of academic texts. But say it I must, for despite the discipline's growing acceptance of such alternative discourse(s), many if not most academic readers remain committed to conventional professional practices of reading. Historically, scholars have submitted to the discipline's view of the self and affect as unauthorized subjects; we've been trained to see authors' revelations of their personal stories or emotions as selfindulgent at worst, irrelevant at best. Thus, many scholars object-sometimes strenuously - to proposals that academics use "the personal" —an individual's affect and/or narrative and/or experience - as a way to renounce mastery and share a common discourse.

Consider, for instance, former CCC editor Joseph Harris's contribution to Publisbing in Rhetoric and Composition, a collection that J. Hillis Miller calls "the best book I know on how to publish scholarship in rhetoric and composition" (xi) and whose jacket promises essays from "contributors [who] are current or past editors of the discipline's most prestigious scholarly journals [and who] undoubtedly have their finger on the pulse of composition's most current scholarship." In his chapter "Person, Position, Style," Harris distinguishes among "three competing aspects of the personal"; he particularly disparages the aspect identified as personal "content," namely "the relaying of autobiographical information about the person writing" (48), claiming that we should "raise some questions about the rumored subversive effects 
of autobiography" at least in part because "most uses of autobiography in scholarly work are in fact quite predictable" (50). Also questionable, he says, is Richard Miller's belief that the reason scholars react "nervously" to an autobiographical move is that it requires them to respond to an author's presence rather than an author's mastery. Harris declares that there's "an economic as well as psychological aspect" (51) to scholars' nervous response and concludes that "there seems something peculiar about downplaying a sense of 'mastery' through calling attention to one's self" (52).

As you have perhaps already predicted, this dissonance between current calls for a more material, affective discourse and a competing commitment to conventional reading habits presents a crucial ethical dilemma in our professional discursive practice: we argue for innovations in our professional writing but remain faithful to conventional logics, gestures, and epistemologies in our reading. In Ethical Dilemmas in Feminist Research Gesa Kirsch helps us recognize some consequences of this ethical dilemma when she explains that "those interested in ethical inquiry must realize that our task is not simply to do research and to publish it, but also to cultivate audiences that can be moved to action by it" (100). Nonetheless, in further considering the politics of publication, she retracts what she calls her earlier "enthusiasm for new textual practices in composition" and says this: "I want to step back and scrutinize my enthusiasm, to articulate some of my reservations [such as] the matter of readability, and the questions of access and utility that attend any act of rhetorical innovation" (69). Feminists' new textual practices, Kirsch concludes, involve "demanding, time-consuming tasks which ask readers to carry out much of the interpretive and analytical work usually done by authors [...]. This is an unusually hard burden for readers to bear, one for which readers expect a significant reward" (72).

That certainly seems true. And it's likewise true that some authors use "the personal" to reveal intimate details of their lives not readily or even tangentially relevant to professional work; to be cloyingly flip or trendy or hip; to satisfy their longing to write creative nonfiction without much academic purpose. Who can really blame readers for being nervous about or disappointed in such writing? I too found it "peculiar" if and when authors submitting pieces for this special issue ignored the needs of College English readers.

But the rhetoric that Kirsch uses- - "readers expect a significant reward"-gives me pause. When Kirsch analyzes readers' needs in economic terms and assumes this economy to be-if not natural —at least beyond reproach, she disempowers feminist authors by charging them with the full burden of "greater interpretive responsibility" for their construction of texts that challenge traditional publication practices (66). In this analysis, Kirsch aligns herself-probably unwittingly-with the same economy of textual consumption that Harris advocates when he claims that "the briskness, clarity, and self-effacement of classic academic prose can be seen not sim- 
ply as a surrender to the logic of patriarchy but also as a kind of deference, as a desire not to impose too much on one's readers" (51). In his view, it's not surprisingcertainly not unethical-if academic readers angrily reject the efforts of an author who "flouts this customary deference and asks the audience instead to attend to his own feelings or experiences," for "it is the reader who has usually paid to attend an academic conference or subscribe to a journal" or-in the currency of sweat equity-to review a manuscript (51). Harris concludes that "there is an economic as well as psychological aspect to this discomfort and anger-that one wants to get what one has paid for" (51).

I read Harris's conclusion as a skewed, narrow, and patrician view of what our textual economy should be. For one, it fails to consider that not just the reader(s) but also the speakers/authors have paid to attend the conference or write for the journal. (Indeed those roles are often filled by the very same individuals.) Second, it assumes that how Harris wants to spend his money is how we all do. Most important, it projects an institutionalized, and therefore most certainly masculinist, ethics and epistemology. Such androcentrism misrecognizes its demand for a feminist author's deference to the authority of an academic reader unwilling to be held accountable for the interpretive authority constructed by bis professional practices.

If we want to commit to a literacy that ends oppression, then perhaps we should be willing to extend ourselves enough to shop more wisely. Perhaps we need to look carefully at our procedures of discourse, the economy driving our discursive practices. Foucault has carefully demonstrated the ways that the author-function "results from a complex operation whose purpose is to construct the rational entity we call an author" and that what we designate as characteristics of the author "are projections, in terms always more or less psychological, of our way of handling the texts: in the comparisons we make, the traits we extract as pertinent, the continuities we assign, or the exclusions we practice" (127). I'd say that expecting "customary deference" is one such practice. What I'm asking us to do instead is to recognize that accountability for discursive practices comprises an academic professional's ethical and interpretive responsibility. This responsibility is not just to feminist theory and method, but to any system grounded in equitable, open-minded exchange.

Here, then, is my first move toward a discursive ethics of professional critical literacy, namely the recognition that our textual economy-the procedures that determine our discursive practices as academics-includes consumption as well as production of our professional texts. At this point in our revisionary view of professional discourse, I want us to consider the ethical dimensions of the economy we're endorsing, particularly the payoffs we expect as well as the assumption that our expectations are (or even should be) similar. (I readily include myself in this "we," since, until now, my scholarly contributions have been most focused on how to write, on how to produce, an embodied rhetoric rather than on how to read it.) We as a pro- 
fession have not yet paid enough attention to our practices of consuming the alternative discourse(s) that we too-not just our students-produce; as a result, our practices undermine, if not censure, innovative textual production, disciplining their subversive potential.

Lunsford and Ede note this phenomenon in their "Writing Back" response to the "Exploring Discontinuities" section of Feminism and Composition Studies:

What significance (if any) should we (or other readers) attach to the fact that your essays tend to accept and embody, rather than to transgress, the conventions of traditional academic prose? Does this acceptance and embodiment mark a place of paradox and difficulty or does it represent a judicious response to your specific rhetorical situations [...]? (318)

The significance I can attach to the phenomenon Lunsford and Ede note is this: if we want to support not just theories but practices that challenge traditional academic prose, then we need to address the ethical imperative for a professional critical literacy that demands that readers, as well as writers, be accountable for the "interpretive burden." Readers must be willing to bear the discomfort involved in avoiding what Royster, in "When the First Voice You Hear Is Not Your Own," refers to as the bad manners of trespassing in Others' territories, speaking over Other voices. Evidence of discursive bad manners would be practices that perpetuate readers' misrecognizing their emotional responses to the theory/opinion they encounter, their positions of professional privilege and power over Others, and their habitual practice-often invisible - of particular choices as interpreters and thus of particular methods of judging and interpreting epistemologies.

One configuration of a more ethical literacy is what Min-Zhan Lu has called "critical affirmation." "At the heart of critical affirmation," Lu explains, is "the tension between individual agency and collective goals of ending oppression" (189). The practice relies on "mark[ing] writing, especially personal narratives, as a site for reflecting on and revising one's sense of self, one's relations with others, and the conditions of one's life" (173).

Obviously, I endorse such a literacy, for it entails directing one's privilege and individual autonomy toward a utopian goal of illuminating rather than masking the oppressive cultural forces inherent in institutional discourse(s). To me, supporting the goal itself constitutes my "reward" for the nervousness, impatience, and other discomfort that come with the burden of developing and learning the new interpretive practices necessary to consuming new textual forms.

Such a goal demands what I call a "discursive ethics" of professional reading practices. This ethics is committed to confronting masculinist and racist privilege, to promoting what Royster identifies as "codes of behavior that can sustain more concretely notions of honor, respect, and good manners across boundaries" "When" 33). In order to enact a discursive ethics, academic professionals must attend to all 
aspects of their experience (thoughts, feelings, memories, or associations) when they grade, review, or otherwise consume texts. In other words, readers must learn to embody their responses as individuals and as professionals. Such embodied reading demands recognizing and being accountable for our often invisible commitment to the professional practice of a particular choice as interpreters and to the oppressive potential that choice has on writers of difference.

This brings me to my second important move toward revising our conventional textual economy, namely offering a few suggestions for developing embodied professional reading practices that sanction a critical, self-reflective awareness of the emotional and ideological origins of our textual interpretations. Though my suggestions are rooted in Royster's and Krista Ratcliffe's outlines for better listening practices, they are also in large part cut from the same cloth as the "recovery writing" I've earlier proposed ("Making Writing Matter"). The fact that my proposals for embodied, ethical reading and writing practices differ little signals the strength of the textual economy they construct: interpretive responsibility is shared and thus insists on collaboration, relationship, between readers and writers.

Not surprisingly, then, one essential of an ethical professional critical literacy would be a willingness to read and respond in order to empower, rather than have power over, the writer. This willingness is crucial, "for embodied writing and reading require me to surrender my analytical need to be right and/or absolute in my understanding of how language [and life] works" ("Making" 101). That surrender reveals the need for another logic, one not based on noncontradiction or supremacy, and a reconception of our purpose as professional readers. In the role of negotiator, Royster tells us, we need to determine our "rhetorical purpose to be to cross, or at least to straddle boundaries with the intent of shedding light" ("When" 34); thus, a discursive ethic demands-especially when we're responding to an author of discourse(s) and/or experience(s) opposing our own or invoking intense affect-that we be "curious enough to try to understand [his or her] voice" ("When" 36 ).

Royster pointedly asks us, "How do we demonstrate that we honor and respect the person talking and what the person is saying?" (38). I see an answer in Ratcliffe's "Rhetorical Listening" and its conception of a new logic of understanding. Unlike the divided logos of traditional "disciplinary and cultural biases [, . . ] the logos that speaks but does not listen," Ratcliffe tells us, a more feminist conception of logos is "based on a desire for an intersubjective receptivity, not mastery, and on a simultaneous recognition of similarities and differences, not merely one or the other" $(202,205)$.

In addition to feminist reading practices that seek to empower authors, another crucial element of embodied reading is relentless self-reflection; the self-reflexivity of an ethical textual economy demands that I continually call attention to the ways I use rhetoric to position myself in relation to texts and authors and to the motives I have for doing so. 
To give you an example of this relentless self-reflection, let me refer to my earlier discussion of Gesa Kirsch's Ethical Dilemmas and contextualize my interpretation. I read that volume as a book reviewer for $\mathcal{F} A C$. I've since used it more than once as a text for graduate methodology as well as feminist theory courses. Clearly, then, and as I declared in the review, I found it a good book, useful. And yet, as a professional reviewer, I felt compelled to find something in the book to disagree with; otherwise, I'd appear too agreeable and compliant, incapable of making "new knowledge" in the field. And indeed I did find such a thing: I pointed out in my review-as I have here-what I see as Kirsch's failure to hold readers as well as writers accountable for their discursive practices. As I write (and you read) at this very moment, I'm cashing in, so to speak, on Kirsch's "flaw" when I-again-use it as a focus for my own argument. Nonetheless, when I foreground-as I am doing now-my awareness of the rhetorical move I'm using to position myself as somehow more masterful than Kirsch on this topic, as an "expert" authorized to speak in the name of the profession, I am in some small way transforming that professional practice by drawing attention to it. Hoping to authorize a feminist ethics of professional discourse, I am embodying my reading (and writing) practices.

As you can see, an embodied, ethical reading demands self-reflexivity. But there's more: it also requires relentless awareness of emotional responses to texts; in fact, my own process often begins in affect. Nevertheless, and exactly like the practices I've already identified as the responsibility of authors of embodied writing, an embodied reading - if it is to be ethical — "transforms my immediate self-absorption with subjective affect into an awareness of not only how my responses have been socially conditioned and socially perceived, but also how I as author [or reader] can intervene in that conditioning" ("Making" 103). Thus, while embodied reading "relies on visceral reactions as the point of departure for examining and revising personal and social practices," the accountability I'm advocating also insists that I "read through" these emotional reactions "in order to recognize how they have been formed [...] to gain awareness of my individual chain of associations as well as the social sites informing those responses" (103).

In order to examine the stakes of my subjective response, I must recognize how the passages that evoked my anger, longing, or "victory" affect my view of myself as a professional, how they might threaten or impede me in my goals of success and self-satisfaction. "Most importantly, taking inventory of my affective responses requires me to scrutinize the fears that belie my vehement insistence [...] that my position is uniquely righteous, factual, exact, superior" ("Making" 103). I might ask myself, what commitment(s) to a practice of a particular interpretive choice do I have and how does this author I'm reading invoke that commitment?

Let me consider my earlier reading of Harris as another example. Right up front, I need to admit that the first time I read "Person, Position, Style"-in particu- 
lar the section on person-I was more than a little peeved. I'll share only three of my visceral reactions: "Bull_—! Sexist, myopic crap!" I scribbled next to Harris's claim that the classic style of academic prose "can be seen not simply as a surrender to the logic of patriarchy but also as a kind of deference, as a desire not to impose too much on one's readers" (51); "Yeah, but you're not the only paying customer!" I responded to his claim that "one wants to get what one has paid for" (51); near the conclusion, I fairly shouted, "You assume that the 'job to be done' is the one you see, you want to be done, the one you want to invest in. What about the rest of us?" As you can probably see, I was reacting to what I read as Harris's attitude (whatever that means), his persona; it seemed so "typically" masculine, one voice assuming authority for everyone.

Now I am quite sure that I'm not the first to get royally ticked off reading academics' work, not alone in my practice of vehemently retorting to others in the margins of my books; I'd say that practice is probably more or less typical. So please consider the possibility, then, that I'm not "confessing" my responses to you because I see myself as guilty or unique. What I mean to do is "read through" my bodily reactions, which clearly position me as feminist, as resistant to traditional authority, maybe as insubordinate or reactionary; perhaps I even seem as guilty of myopic selfcenteredness as the writer I'm castigating. I can trace-and have traced (see "Authorizing Anger")-my own private chain of associations and discovered the familial roots of my resistance to patriarchal authority and my penchant for feminist reading practices. In this context, however, I choose to focus on the social, professional sites of my consumption and reproduction of Harris's article.

This is the third (or is it the fourth?) time that I-as a feminist arguing for personal criticism-have contested in print Harris's "person" claims in that article. Apparently, I feel compelled to prove him wrong. Fortunately for me, then, the conventions of academic discourse sanction (I could even say "require") my gesture toward another author's "flaw" and my subsequent correction of it. Being disciplined to rely on such gestures so that my own academic prose will be published and my profession(al position) secure, I've learned a composing process whose invention comes about by constructing others' fault(s). Thus, I made a valuable discovery when I first read that article, or perhaps it's more accurate to say that I've mastered it, made it valuable (to me) by reading it the way I have. In fact, it might even be fair to say that I've been self-indulgent in insisting on the article's relevance so many times, that my first or even second challenge was okay but thereafter I've been beating that proverbial horse. Though I could, perhaps, have justified my insistent critique of Harris's view of personal writing by referring to its inclusion in a volume intended to shape novice professionals' writing styles and/or to his power to shape the discipline's discourse when he served as editor of $C C C$, I think it a safe bet that the "briskness, clarity, and self-effacement of classic academic prose" have-up till now- 
justified if not masked my indulgence. But now that I am pointing it out to you, now that I am considering my own accountability in critiquing Harris's piece, am I acting more or less self-indulgently? Am I renouncing mastery or claiming it? Is it me or is it us, our practice, that I am asking you to scrutinize here? Is posing these questions in either/or terms even relevant or useful to my goal of ending oppression in professional discourses?

And speaking of scrutinizing, I need to acknowledge that writing this particular critique of Harris's chapter sent me back to his text in order to better contextualize my earlier objections. I (re)discovered that after his discussion of "person," in his next section, entitled "Position," he presents several examples of what he considers appropriately personal academic writing. "What all this work shares," he says, "is a kind of disciplined subjectivity, a willingness to acknowledge one's own position within the profession and culture as a driving force behind (and also a limit on) what one has to argue" (55). Hmm, that sounds pretty reasonable to me; in fact, it could even describe what I'm doing here. So could Harris's earlier reference to Clifford Geertz's belief that "writers can make themselves present in their texts not only through autobiography but also through trying to state what draws them to the subject or issue at hand [...] what they see as being at stake for both themselves and others in that discussion" (52). He and I are more of the same mind than I had thought. Perhaps we part ways only because I can't buy into his insistence that person, position, and style are competing aspects of the personal; his belief that a writer's relaying personal information about himself or herself-the use of autobiographyis confessional and therefore inappropriate in academic arenas; nor finally his conviction that most scholarly uses of autobiography are predictable. I hope the pieces included in this special issue prove me reliable.

But I do have to admit that there's no logical reason that I'm right and he's not, no foundation preventing Harris from offering the same critique of my position that I've presented (ad infinitum) of his. After all, why should I have any more authority than he does to determine what counts as getting "what one has paid for"? What gives me a corner on the ethics market? And if we want to compare attitudes-well, mine tends to be pretty flippant, less prudent. If I commit to the discursive ethics I've been advocating here, then I need to own up to not seeing much-if anyrational difference between Harris's argument and my critique of it. Rhetorically, however, I do see important differences, for I have at least tried to gesture to the personal stakes and affect motivating my critique. It's not much, perhaps, but it's something that decenters the logic of patriarchy. I have tried to convince you that we should all commit to a certain discursive ethics; however, I haven't (totally) obscured my personal motives or myself by using "one" instead of "I," by masking my preference for a certain type of personal writing in an attempt to legislate all types.

This focus on rhetoricity is as crucial to embodied reading as it is to embodied 
writing. Combined, the two provide a discursive ethics of professional critical literacy that empower the goals, politics, and textual economy of difference. As I've said of embodied writing, ethical professional reading requires me to engage rather than ignore problems of interpretation and meaning. It

grants me powers of analysis while pressing me to reflect on how my knowledge, affect, and taste are produced by the specific social locations which define me [...]. The discursive tools of recovery writing [and of ethical reading are] crucial to recognizing myself personally and professionally as part of a larger social network, as well as (or sometimes rather than) an individual target of an individual enemy. Embodied writing [and reading have] helped me see that it is in the gaps of the contradictory positions and emotions where I can learn the most, [for] it is in the interplay of my attempts to mediate those contradictions that I can best become aware of those sometimes invisible ideologies that discipline me and those social institutions which construct me. ("Making" 105-06)

I'm sure that I am not alone in my yearning to answer Royster's incisive call for us to "construct paradigms that permit us to engage in better practices in crossboundary discourse, whether we are teaching, researching, writing, or talking with Others, whoever those Others happen to be" ("When the First Voice" 37-38). Since our reading(s) of their texts is clearly a means of "talking with Others," I ask us to acknowledge the ramifications of our practices as textual consumers, to be accountable to people as well as ideas and to one another as much as if not more than to an abstract "body of knowledge." A discursive ethics that requires me to evoke my beliefs at their most invisible embodied place, to scrutinize relentlessly the stakes in maintaining those individual beliefs and confront the privileges they afford me, and to stage self-consciously my methods for persuading you of the authority of those beliefs-that kind of reading and interpreting will contribute, I believe, to an economy of discourse that is ethical. In that economy, readers' and writers' 'significant reward" could be just what Royster envisioned: "[D]iscourse invigorated with multiple perspectives, [...] policies and practices well-tuned toward a clear respect for human potential and achievement [...] and a clearer understanding that voicing at its best is not just well-spoken but also well-heard" (40). To me that seems like getting my money's worth. Here's hoping you, too, get your reward—or at least don't feel cheated - as you read the embodied writing that follows.

\section{Works Cited}

Bizzell, Patricia. "Feminist Methods of Research in the History of Rhetoric: What Difference Do They Make?” Rhetoric Society Quarterly 30 (2000): 5-17.

Foucault, Michel. "What Is an Author?" Language, Counter-Memory, Practice: Selected Essays and Interviews. Ed. Donald F. Bouchard. Trans. Donald F. Bouchard and Sherry Simon. Ithaca: Cornell UP, 1977. 113-38. 
Harris, Joseph. "Person, Position, Style." Publishing in Rhetoric and Composition. Ed. Gary Olson and Todd Taylor. Albany: SUNY P, 1997. 47-56.

Hindman, Jane E. “Authorizing Anger: A Personal Encounter with Plato's Gorgias." Pre/Text: ElectraLite 1.1 (1997). 7 Apr. 2003 http://www.utdallas.edu/pretext/PT1.1/PT1Hind.html.

"Making Writing Matter: Using 'the Personal' to Recover[y] an Essential[ist] Tension in Academic Discourse." College English 64 (2001): 88-108.

- Review of Etbical Dilemmas in Feminist Researcb: The Politics of Location, by Gesa Kirsch. FAC 19 (1999): 742-46.

. "Writing an Important Body of Scholarship: A Proposal for an Embodied Rhetoric of Professional Practice." FAC 22 (2002): 93-118.

Jarratt, Susan C., and Lynn Worsham, eds. Feminism and Composition Studies: In Other Words. New York: MLA, 1998.

Kirsch, Gesa. Ethical Dilemmas in Feminist Research: The Politics of Location, Interpretation, and Publication. Albany: SUNY P, 1999.

Lu, Min-Zhan. "The Politics of Critical Affirmation." CCC 55 (1999): 172-94.

_. "Reading and Writing Differences: The Problematic of Experience." Jarratt and Worsham. 23951.

Lunsford, Andrea Abernethy. "Rhetoric, Feminism, and the Politics of Textual Ownership." College English 61 (1999): 529-44.

Lunsford, Andrea, and Lisa Ede. "Writing Back." Jarratt and Worsham 313-20.

Miller, J. Hillis. Foreword. Publishing in Rhetoric and Composition. Ed. Gary Olson and Todd Taylor. Albany: SUNY P, 1997. xi-xv.

Miller, Richard E. “The Nervous System.” College English 58 (1996): 265-86.

O'Donnell, Thomas G. "Politics and Ordinary Language: A Defense of Expressivist Rhetorics." College English 58 (1996): 423-39.

Ratcliffe, Krista. "Rhetorical Listening: A Trope for Interpretive Invention and a 'Code of Cross-Cultural Conduct." CCC 51 (1999): 195-224.

Royster, Jacqueline Jones. Traces of a Stream: Literacy and Social Change among African American Women. Pittsburgh: U of Pittsburgh P, 2000.

—. "When the First Voice You Hear Is Not Your Own." CCC 47 (1996): 29-40.

Worsham, Lynn. "Écriture Féminine in Composition Studies." Contending with Words: Composition and Rhetoric in a Postmodern Age. Ed. Patricia Harkin and John Schilb. New York: MLA, 1991. 82-104.

. "On the Rhetoric of Theory in the Discipline of Writing: A Comment and a Proposal." FAC 19 (1999): 389-409. 